Kong. Res. J. 3(2) : 104-112, 2016

ISSN 2349-2694

Kongunadu Arts and Science College, Coimbatore.

\title{
FORAGING DYNAMICS AND POLLINATION EFFICIENCY OF APIS CERANA INDICA (HYMENOPTERA : APIDAE) ON EGGPLANT, SOLANUM MELONGENA L.
}

\author{
Eswaran, $\mathbf{R}^{1^{*}}$,, K. Anand ${ }^{1}$, S. Baskaran ${ }^{2}$ and P. Pramod ${ }^{3}$ \\ ${ }^{1}$ Department of Zoology, The Madura College, Madurai- 625011, Tamil Nadu. \\ 2Department of Zoology, Ayya Nadar Janaki Ammal College, Sivakasi- 626124, Tamil Nadu. \\ ${ }^{3}$ Salim Ali Centre for Ornithology and Natural History (SACON), Anaikatty, Coimbatore - 641 108, Tamil Nadu \\ *E.mail: eswarbutterfly@gmail.com
}

\begin{abstract}
Bees are responsible for more than $50 \%$ of all successful pollination. The pollination efficiency of Apis cerana indica was studied in Eggplant, Solanum melongena. The Apis cerana indica was found to spend 20 sec./flower/visit $(20 \pm 1.58)$. The amount of pollen depleted by Apis cerana indica was 563 pollen grains/insect visit (562.8 \pm 34.89 ) and pollen deposition was 197 pollen grains/insect visit (196.8 \pm 19.31$)$. Pollen depletion and deposition by Apis cerana indica were more during 0800-1000 hrs. The peak activity of bees was recorded at $0900-1100 \mathrm{hrs}$ when the temperature ranged from $28-32^{\circ} \mathrm{C}$ and humidity ranged from 58-73\%. The diurnal activity Apis cerana indica showed a significant positive correlation with temperature and negative correlation with humidity. These results showed Apis cerana indica is one of the efficient pollinators for Solanum melongena. The importance of Apis cerana indica colony for the improvement of agriculture is also be discussed.
\end{abstract}

Keywords: Insects, Bees, Apis cerana indica, pollination, pollinators.

\section{INTRODUCTION}

Insects are very important pollen transporters and they account for $85 \%$ of all pollination (Price, 1984; Decourtye et al., 2010). Beetle, Bees, wasps, ants, flies and butterflies are the most common insect pollinators and bees account for more than $70 \%$ of the insect pollination (Abrol, 1993; Rakesh Kumar et al., 1997; Subba Reddy et al., 1997). The interaction between the insect pollinators and the plants is a mututulaistic relation (Aguiar et al., 2015)

Nectar and pollen are the most common rewards offered by flowering plants to flower visitors in return and providing a pollination service (Simpson and Neff, 1983). Nectar is a phloem sap derivative and is a complex mixture of sugars, aminoacids, proteins, lipids, antioxidants, alkaloids, vitamins and minerals (Kevan and Baker, 1983). It is secreted by locally densely packed groups of specialized cells (nectaries) located on petals or sepals (Richards,1986). The nectar provided by the flowers has been found to be a significant parameter that shapes the pollinator behaviour to their energetic needs (Heinrich, 1975). Nectar is often the only source of energy for the activity, maintenance of metabolism, reproduction and growth of certain pollinators (Heinrich and Raven, 1972). Nectar is a renewable resource. Removal of it by bees visit and by microclimate with continuing secretion and therefore at the end of the day, after frequent bee visits, the nectar available would be of recent origin (Vithanage and Douglas, 1987). As the volume of nectar per flower decreases, the bees can expand its collecting area, but not indefinitely (Pflumm, 1985).

Pollen is considered to be the primitive flower reward. Pollen is highly nutritive and contains essential and quasi-essential aminoacids(Shubharani et al., 2012). Pollen is a vital food for many insects especially apidae (larva), flies, beetles, thrips and butterflies (Kevan and Baker, 1983). The amount of pollen presented by each flower is predetermined long before it opens. However, the flowers could adapt themselves in such a way that this nonrenewable reward is presented at a time when the other rewards are most attractive (Vithanage and Douglas, 1987). In Macadamia, Macadamia Spp. adapt in such a way that the pollen reward is presented at a time when other rewards are most attractive. It helps to attract more number of bees (Vithanage and Doughlas, 1987). In Antigonon leptopus L. (polygonaceae), the anthers become dry and turn black by the evening time (Solomon Raju et al., 1999). Pollen is the principle source of non-liquid food and is the ultimate source of protein and lipid. 
It is responsible for the growth and maturity of honeybees (Saraf, 1987).

Pollen dispersal success in entomophilous plants is influenced by the amount of pollen produced per flower, the fraction of pollen that is exported to other flowers during a pollinator visit, visitation frequency and the complementary between donor and recipients (Galen and Stanton, 1989). Most flowers open in the morning and pollen collector are active then. The pollen availability is high at this time and gradually declines during the day (Vithanage and Douglas, 1987).

Insect pollinators especially bees play a vital role in improving both quantity and quality of crops. In three rabbit eye blueberry cultivars (Vaccinium ashei Reade) bee pollinated flowers showed greater fruit numbers (Ne Smith and Krewer, 1999). In litchi, Litchi chinensis Sonn. honey bee pollinated flowers produced large sized fruits and 8.17-18.18\% increase of fruit weight (Badiyala and Garg, 1990). In white mustard, Brassica alba, the plots which remained without access to pollinators (cage without any pollinator) had the lowest yield (966 $\mathrm{kg} / \mathrm{ha}$.), plots having free access to all the pollinators showed maximum yield (1620 kg/ha.) followed by plots having honeybees, Apis cerana Fabr. (1160 kg/ha.) (Chand and Singh, 1995). In both PSFH-67 and MSFH-8 varieties of sunflower, Helianthus annuus L. plots having open access to all the insect visitors had significantly high seed setting (72.36 and $72.50 \%$ respectively) followed by the plots caged with bees (Apis mellifera L.) (68.90 and 69.86\%). In cucumber, Cucumis sativus L., Apis mellifera L. played an important role in the maximum production of a cucumber crop, and the duration of honey bee visits to flowers was correlated positively to the numbers of cucumber produced, to their weight and to their maximum girth (Gingrass et al.,1999). In cherry production, the blue orchard bee, Osmia lignaria increased the yield at about 2.68 fold (Bosch and Kemp, 1999). Cross pollination by various pollination agencies plays a pivotal role in increasing the yield of most of the fruit crops (Badiyala and Garg, 1990).

Abrol (1993) stated that the number of insects on a crop is directly related with temperature and inversely with relative humidity. In ridge gourd, Luffa acutangula, the diurnal activity of the wasp and Apis cerana indica showed insignificant positive correlation with the temperature. The foraging activity of the wasp showed insignificant negative correlation with the humidity, whereas Indian bee (Apis cerana indica) showed insignificant positive correlation with the humidity on sunny and cloudy days (Baskaran et al., 1997). In Apiaceae plants, bee abundance was shown to be significantly correlated with air temperature, light intensity, solar radiation and nectar concentration but negatively with relative humidity (Koul et al., 1993). In almond, Prunus amygdalus, the foraging activity of Apis cerana indica and Xylocopa fenestrata showed a negative correlation with humidity on sunny days (Abrol, 1988). Temperature and humidity influence the foragers activity through the drying of anther and pollen. Anthers dry at high temperature (Freeman and Head, 1990).

The efficiency of pollinator is dependent on number of factors, such as, the number of pollen grains collected at flower visits, the number of pollen grains delivered at subsequent flower visits and the number of pollen grains germinating on the stigma producing pollen tube that reach the ovules (Wiklund et al., 1979).

Due to human activities through modernization, natural populations of pollen bees have declined in many years (Batra, 1994; Cameron et al., 2011). Thus, since the 1950s it has become necessary to use honeybees for pollination and develop methods to artificially raise or manage pollen bees for use on some crops. Interrelationship between plants and pollinators has been well studied in temperate zone while little is known from tropical zone (Ram,1980).

In recent years, researchers started collecting limited data on the importance of insect pollinators in commercial crops in tropics. There is an urgent need to undertake such studies in every plant family (Schmitt,1980). Such a need is much more intense in India, where there is a dearth of even a basic data (Reddi and Reddi, 1983). Also efficiency of bees on pollination of the commercial crops is less studied. Hence, it was proposed to study the "Insect Pollination of Eggplant, Solanum melongena L." with focused on the pollination efficiency of Apis dorasata in Solanum melongena

\section{MATERIALS AND METHODS}

\subsection{Study period}

For the present study, the of eggplant, Solanum melongena L. field situated in the village Anaiyur, Sivakasi Taluk, Virudhunagar District, Tamil Nadu was selected as study areas. The study was conducted during January 2001 to study the following parameters. 


\subsection{Compositiion and relative abundance of flower visitors.}

This parameter was determined following the method of Jyothi et al. (1990). The insects that visited flowers during the study period were collected and identified. Relative abundance of each insect visitor was calculated by watching the number of visits of each insect visitor for 10 minutes $/ \mathrm{hr}$. from $0600 \mathrm{hrs}$ to $1800 \mathrm{hrs}$ in an area of one square meter. From this data the number of visits per day was calculated.

\subsection{Pollen depletion}

The amount of pollen carried from a flower by an insect is called as pollen depletion. This was studied following Solomon (1945).

\subsubsection{Collection of insect visitors for pollen count}

For pollen count the insect visitors were collected by placing a clean specimen tube over the insect while foraging and then closed with a stopper. Then the collected insects were anaesthetized immediately by placing chloroform soaked cotton plug over the mouth of the specimen tube. The specimen tubes were taken to the laboratory and stored in refrigerator until the insects were taken out for examination. In case of bees, the pollen baskets were discarded by removing the hind legs, as the pollen grains present in the pollen baskets are not used for pollination.

\subsubsection{Pollen count}

For the pollen count, the collected insects were taken out from the refrigerator and each insect was held with forceps over a small petridish. A fine jet of $70 \%$ ethyl alcohol was sprayed over the entire surface of the insect, which was then held under the liquid in the petridish and brushed with a small camel hair brush. Finally the insect was taken out from the liquid and sprayed again with a jet of alcohol. Then this sample was poured into a counting chamber. The pollen was allowed to settle and stirred well for uniform distribution of pollen grains in the counting chamber. The number of pollen grains was counted by a compound microscope.

\subsubsection{Pollen deposition}

Pollen deposition is the amount of pollen deposited on the stigma by an insect. To assess the amount of pollen deposited on the stigma, the flowers bagged with polythene cover just before anthesis (Plates $3 \& 4$ ) were opened one by one for the insect to visit following the method of Reddi and
Reddi (1983). When such flowers received the first visit, their stigmas were plucked and examined for the number of pollen deposited following the pollen count method as mentioned earlier.

\subsubsection{Time spent at flowers}

This was calculated for each visitor using a stop watch, when an insect approaches the flower the stop watch was switched on and when it leaves the flower, it was switched off (Reddi and Reddi, 1983).

\subsubsection{Diurnal activity}

Diurnal activity is the foraging activity of insect visitors during day time from $0600 \mathrm{hrs}$ to 1800 hrs. This was studied following the method suggested by Abrol (1987). The diurnal activity of insect visitors was studied by watching the number visits of insects for 10 minutes/hr. from $0600 \mathrm{hrs}$ to $1800 \mathrm{hrs}$ on the plant population in one square meter. Concurrent with foragers counts, measurements of environmental factors such as temperature and relative humidity were also made in the experimental field by using comfort meter.

\subsubsection{Temporal variation in pollen depletion from anthers and pollen deposition on stigma.}

Temporal variation is the variation in the pollen depletion from anthers and pollen deposition on stigma in relation to time. This was done following the method suggested by Reddi and Aruna (1990). Here the pollen depletion and pollen deposition by insect visitors were studied at an interval of two hours from $0600 \mathrm{hrs}$ to $1800 \mathrm{hrs}$.

\section{RESULTS AND DISCUSSION}

The flowers of egg plant, Solanum melongena L. were found visited by Indian bee, Apis cerana indica; Little bee, Apis florea; Rock bee, Apis dorsata; Anthophorid bee, Anthophora zonata, Carpenter bees, Xylocopa violaceous; and Xylocopa aestuans. Among the bees, Apis cerana indica (25\%) was of the second major visitor next to Apis dorsata (Fig. 1). This is due to the fact that hymenoptera is the most important order of anthophilous insects (Kevan and Baker, 1983). Bees are the most important among all angiosperm pollinators (Grissell, 1999; Rosa et al., 2015). The honeybees represented about $90 \%$ of the total number of insects visiting the watermelon crop (Hadimani et $a \mathrm{l} ., 1998)$. The dominance of hymenopterans is due to their adaptive structures in their body. The body of honeybee is covered with branched hairs for the pollen to adhere (Elzinga, 1987). 
Apis cerana indica was found to spend 20 sec./flowers/visit on flowers (Table 1). In apple, Malus domestica, the foraging bees such as A. cerana indica, A. mellifera, A. dorsata, Epi balteatus, E. tenax and Orthellia Spp. spent on average 7.92, 11.40, 6.46, 38.26, 25.80 and 43.60 seconds per flower (Dashad et al., 1994).

In guava, Psidium guajava L., the time spent per flower by A. mellifera, A. dorsata and A. cerana indica were 5.8, 5.2 and 4.0 seconds respectively (Rakesh Kumar et al., 1996). The varying time spent by different species of thrips in solanaceae plants reflects the degree of host specificity (Annadurai and Noble Marrison, 1987). Honeybees, Apis cerana indica and Apis dorsata spent the same time $(2.3 \mathrm{sec}$.) on each head for pollen collection but took $3.7 \mathrm{sec}$. and $3.9 \mathrm{sec}$. respectively for nectar collection on niger, Guizotia abyssinica (Mohana Rao and Suryanarayana, 1990). In sunflower (Helianthus annuus L.), the average time spent per capitulum by Apis and Xylocopa bees was $47.87 \mathrm{sec}$. and $34.58 \mathrm{sec}$. respectively (Abrol, 1996). Mohana Rao and Suryanarayana (1990) reported that in niger, Guizotia abyssinica, the honeybee (Apis cerana indica) spent $3.7 \mathrm{sec}$. and $3.9 \mathrm{sec}$. respectively while collecting pollen and nectar respectively. In scented methi (Trigonella corniculata L.), A. cerana indica and Apis florea spent 5.7 and 10.5 seconds respectively on each flower (Mohana Rao, 1991). The time spent at the flower is an indication of the mobility of an insect which in turn, indicates the effectiveness to utilize the floral resource (Baskaran et al., 1997).

The amount of pollen depleted by Apis dorasata was $562.8 \pm 34.89$ pollen grains/insect visit (Table 1). The pollen loads on bees foraging are related to size of the pollinator (Free and Williams, 1972; Elzinga, 1987). Most small insects with smooth bodies carry little or no pollen whereas large hairy insects bear considerable amount of pollen (Kendall and Solomon, 1973).

Pollen carry over is affected by size and hairiness of the pollinator and its cleaning and foraging behaviour. As honeybees move on the flower, pollen is picked up by plumose body hair, the pollen is brushed off by their legs into pollen baskets on the hind legs (Elzinga, 1987). The body of honeybee is covered with branched hairs for the

pollen to adhere. This makes the honeybees efficient in pollen depletion. The body of honeybees is covered with branched hairs for the pollen to adhere. This makes the honeybees efficient in pollen depletion. Body setae density of bees determines their pollination efficiency (Free, 1993).

Table 1. Time spent at flowers, Pollen depletion and deposition by Apis cerana indica in Eggplant, Solanum melongena $\mathrm{L}$.

\begin{tabular}{lc}
\hline \multicolumn{1}{c}{ Parameters } & Mean \pm SD \\
\hline Time Spent (Sec./ Flower / Visit) & $20.0 \pm 1.58$ \\
Pollen depletion & $562.8 \pm 34.89$ \\
(Pollen grains / Insect visit) & \\
$\begin{array}{l}\text { Pollen deposition } \\
\text { (Pollengrains / Stigma / Insect } \\
\text { visit) }\end{array}$ & $196.8 \pm 19.31$ \\
\hline
\end{tabular}

Table 2. Pollen depletion and deposition by Apis cerana indica in Eggplant, Solanum melongena $\mathrm{L}$.

\begin{tabular}{ccc}
\hline $\begin{array}{c}\text { Time } \\
\text { in Hours }\end{array}$ & $\begin{array}{c}\text { Pollen } \\
\text { Depletion }\end{array}$ & Pollen Deposition \\
\hline 06.00 & $\mathrm{NV}$ & $\mathrm{NV}$ \\
08.00 & $438.6 \pm 46.21$ & $176.8 \pm 21.55$ \\
10.00 & $473.2 \pm 53.28$ & $196.8 \pm 15.42$ \\
12.00 & $423.2 \pm 29.24$ & $186.6 \pm 14.94$ \\
14.00 & $\mathrm{NV}$ & $\mathrm{NV}$ \\
16.00 & $370.2 \pm 38.19$ & $186.2 \pm 18.86$ \\
18.00 & $\mathrm{NV}$ & $\mathrm{NV}$ \\
\hline
\end{tabular}

Values represent $X \pm S D$ of five readings; $N V=$ No visits.

Table 3. Diurnal activity of Apis cerana indica of Eggplant, Solanum melongena L. on a sunny day and cloudy day

\begin{tabular}{ccc}
\hline Time (Hrs.) & $\begin{array}{l}\text { Sunny day } \\
(\mathbf{2 9 - 0 1 - 2 0 0 1 )}\end{array}$ & $\begin{array}{l}\text { Cloudy day } \\
(\mathbf{1 3 - 0 1 - 2 0 0 1 )}\end{array}$ \\
\cline { 2 - 3 } 0600 & - & - \\
0700 & 1 & - \\
0800 & 2 & 2 \\
0900 & 4 & 3 \\
1000 & 6 & 4 \\
1100 & 9 & 6 \\
1200 & 5 & 5 \\
1300 & 4 & 3 \\
1400 & 2 & 2 \\
1500 & 3 & 1 \\
1600 & 2 & 1 \\
1700 & 2 & - \\
1800 & - & - \\
\hline
\end{tabular}




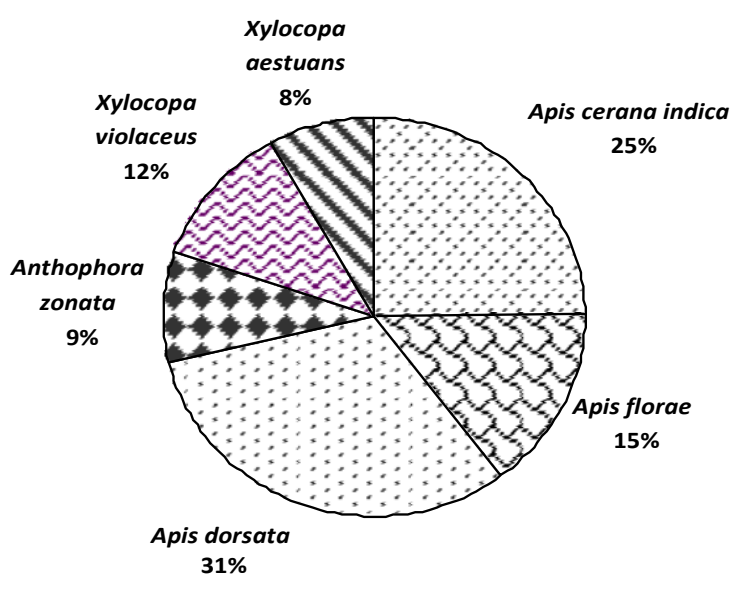

Fig. 1. Composition of bee pollinators of Eggplant, Solanum melongena

Pollen depletion and deposition by Apis cerana indica was more during $10.00 \mathrm{hrs}$ (Table 2). This may be due to the availability of abundant pollen in morning hours (Spira et al., 1992). In morning hours, the Apis Spp. were found to deplete and deposit more number of pollen grains in Brassica compestris L. Var. toria blossoms in the mid hills of Himachal Pradesh (Jitender Kumar et al., 1994). Pollen harvesting rate was more in morning than in evening corresponding to decreasing pollen availability (Buchmann and Shipman, 1990). The hourly observations indicated that bees visited less number of flowers per minute in the morning than at noon and evening time. This may be due to availability of pollen in the flower in large quantities in the morning (Mohana Rao et al., 1984). Most flowers open in the morning and pollen collectors are active then. The pollen availability is high at this time and gradually declines during the day (Vithanage and Douglas, 1987). The pollen gathering activity of Apis mellifera and Apis cerana indica on mustard was more in the morning than in the evening (Thakur et al., 1982).

The amount of pollen depleted and deposited was found to be more at $0800 \mathrm{~h}$. due to pollen stickiness and stigma receptivity in guava, Psidium guajava. The amount of pollen deposition was found to decrease during successive visits of Apis cerana indica (Prakash et al., 1993). This decrease may be due to the decreasing receptivity of stigma with time which is influenced by temperature and humidity (Shivanna and Johri, 1985). The pollen loads carried by bees were heavier for the foraging trips in the morning than those of afternoon in sunflower, Helianthus annuus L. (Bhuyan and Bhatta charryya, 1998). In cotton, Gossypium Spp. the peak time of pollen depletion by A. mellifera L. on the stigma was between 1000 and 1200 hours (Mamood et al., 1990). Among the flower visitors of onion bloom (Allium cepa L.), the maximum number of pollen grains was carried by $A$. dorsata and dipterans carried comparatively less number of pollen grains (Priti, 1998). The size of the pollen loads of bees foraging on polleniferous flowers was larger than that of bees from nectariferous flowers (Neeman et al., 1999). The pollen depletion and deposition were $76 \%$ during the period of $0800-1400$ hours in the flower of Alangium lamarkii (Byragi Reddy and Aruna, 1990). In Delphinium virescens, the amount of pollen deposited on the body of bees during visit is directly proportional to the amount of anthers. The amount of pollen deposited on the stigma of a flower is directly proportional to the amount of pollen carried by the bees' body (Waddington, 1981).

The diurnal activity of Apis cerana indica was mostly found to begin around 0700 hours on sunny days (Table 3 ). The peak activity of all the visitors was found at 1000-1200 hours when the temperature ranged from $29-31^{\circ} \mathrm{C}$ and humidity ranged from $65-70 \%$. The activity of these insects was found to cease mostly around 1700-1800 hours on sunny days. In Zizyphus mauritiana (Rhamnaceae), bees showed maximum activity between 0900 and 1100 hours then decreased gradually (Ramadevi et al., 1989). In the present study, the activity of insect visitors was found to begin around 0700 hours in sunny days and around 0800 hours in cloudy days. The activity was found to cease mostly around 1700 to 1800 hours on sunny days and around 1500 hours during cloudy days. Insects visit were least common during lowlight, moderate winds, lowest temperatures and earliest time of the day. High probabilities of visitiation were found during middle of the day, at high temperature, high light levels, at low humidity and with moderate wind speed (Mc Call and Primack, 1992). Abrol (1993) stated that the number of insects on a crop is directly related with temperature and inversely with relative humidity. In ridge gourd, Luffa acutangula, the diurnal activity of the wasp and Apis cerana indica showed insignificant positive correlation with the temperature. The foraging activity of the wasp showed insignificant negative correlation with the humidity, whereas Indian bee (Apis cerana indica) showed insignificant positive correlation with the humidity on sunny and cloudy days (Baskaran et al., 1997).

The diurnal activity of Apis cerana indica was mostly found to begin around 0800 hrs during 
cloudy day (Table 3). The activity of these insects was found to cease around $1600 \mathrm{hrs}$. The peak activity of Apis cerana indica was recorded at 11001200 hrs when the temperature ranged from 29$30^{\circ} \mathrm{C}$ and humidity ranged from $65-69 \%$. In scented methi (Trigonella corniculata L.), the honeybee ( $A$. cerana indica) initiated foraging from 0920 and completed at $1830 \mathrm{~h}$. The density was maximum at $1400 \mathrm{~h}$. and gradually their population reduced. $A$. florea foraged from 1020 to $1700 \mathrm{~h}$. (Mohana Rao, 1991). In niger, Guizotia abyssinica, the density of $A$. cerana indica was peak at $0900 \mathrm{~h}$. then density gradually decreased. The density of $A$. dorsata was high between 0900 and $1600 \mathrm{~h}$. (Mohana Rao and Suriyanarayana, 1990). The honeybee, A. cerana indica showed peak activity during 0700 - 1000 hours and 1400 - 1500 hours. Xylocopa was most active during the earlier part of the day at 0700 0900 hr. in sunflower, Helianthus annuus L. (Abrol, 1996). The Trigona bees reached peak of abundance on flower between 1000 and $1200 \mathrm{hr}$. whereas honeybees reached a peak at $1230 \mathrm{hr}$. on macadamia flowers (Heard and Exley, 1994). In litchi, Litchi chinensis, A. cerana indica visits were maximum during 0900 and $1100 \mathrm{hr}$. The visits were less during 1400 - 1600 hr. (Mahanta and Rahman, 1997). The peak activity of $A$. cerana indica was during 0900 to $1100 \mathrm{hr}$. on mango flowers (Jyothi, 1994).

Correlation analysis of diurnal activity of Apis cerana indica showed significant positive correlation with temperature $(r=0.647 \mathrm{p}=0.05)$ and negative correlation with humidity $(\mathrm{r}=-0.529$ $\mathrm{p}=0.05$ ). In Apiaceae plants, bee abundance was shown to be significantly correlated with air temperature, light intensity, solar radiation and nectar concentration but negatively with relative humidity (Koul et al., 1993). In almond, Prunus amygdalus, the foraging activity of Apis cerana indica and Xylocopa fenestrata showed a negative correlation with humidity on sunny days (Abrol, 1988). Temperature and humidity influence the foragers activity through the drying of anther and pollen. Anthers dry at high temperature (Freeman and Head, 1990). In Zizyphus mauritiana, the bee activity was positively correlated with air temperature, light intensity, solar radiation, nectar sugar concentration and negatively correlated with relative humidity (Sihag and Abrol, 1986).

The number of insect visitors on lucerne was inversely related to relative humidity (Cirudarescu, 1971). In ridge gourd, Luffa acutangula the foraging activity of wasp showed negative correlation with humidity, whereas, Apis cerana indica showed positive correlation (Abrol, 1993).
The foraging activity of Apis cerana indica and Apis florea showed positive correlation with humidity in guava (Prakash et al., 1993) The foraging activity of honeybees was maximum at those hours when relative humidity was low in sun flower, Helianthus annuus (Panda et al., 1991). Temperature and humidity influence the foragers' activity through the drying of anther and pollen. Anthers dry at high temperature (Freeman and Head, 1990).

Further studies are needed to explore stigma receptivity, temporal variation in floral rewards, influence of light intensity, solar radiations and wind speed on foraging activity of insects which may enlighten new principles on insect visitors of bitter gourd and eggplant.

\section{REFERENCES}

Abrol, D.P., (1987). Activity, time budget and pollination of Apis cerana indica workers. Environ. Ecol. 5 (4) : 707-709.

Abrol, D.P., (1988). Pollination studies in almond (Prunus amygdalus L.). Curr. Sci., 57 (7) : $397-$ 398.

Abrol, D.P., (1993). Insect pollination and crop production in Jammu and Kashmir. Curr. Sci., 65 (3) : 265-269.

Abrol, D.P., (1996). Sunflower pollination: abundance and diversity of pollinating insects and their effect on seed yield. Indian Bee J., 58 (2) : 60-63.

Aguiar, W. M., G. A. R. Melo, and M. C. Gaglianone, (2014). Does Forest phisiognomy affect the structure of orchid bee (Hymenoptera, Apidae, Euglossini) communities? A study in the Atlantic forest of Rio de Janeiro state, Brazil. Sociobiology 61: 68-77.

Annadurai, R.S. and M. Noble Morrison, (1987). Impact of pollen food on the fecundity and feeding time in two species of thrips (Insecta : Thysanoptera) infesting flowers of Solanaceae. Curr. Sci., 56 (9) : 1032-1033.

Badiyala, S.D. and R. Garg, (1990). Studies on the pollination and fruit production by Apis mellifera L. in seven cultivars of litchi (Litchi chinensis Sonn.). Indian Bee J., 52 (1-4) : 28-30.

Baskaran, S., M. Kasthuribai, and K. Paramanandham, (1997). Insect visitors of ridge gourd, Luffa acutangula Roxb. Indian J. Ecol., 24 (1) : 94-97.

Batra, S.W.T., (1994). Diversity with pollen bees. Amer. Bee J., 134 (9) : 591-593. 
Benedek, P., (1976). Effect of environmental factors on the foraging rates of honeybees in the red clover fields. A. A., 29 (3) : 177.

Berger, L.A., B.E. Vaissiere, J.O. Moffett and S.J. Merritt, (1988). Bombus Spp. (Hymenoptera : Apidae) as pollinators of male-sterile upland cotton on the Texas high plains. Environ. Entomol., 17 (5) : 789-794.

Bhuyan, M. and Bhattacharryya, (1998). Honeybee foraging upon sunflower (Helianthus annuus L.) under the agro-climatic condition of Jorhant, Assam, India. Indian Bee J., 60 (2) : 87-90.

Bosch, J. and W.P. Kemp, (1999). Exceptional cherry production in an orchard pollinated with blue orchard bees. Bee World, 80 (43) : 163-173.

Buchmann, S.L. and C.W. Shipman, (1990). Pollen harvesting rates for Apis mellifera L. on Gossypium (Malvaceae) flowers. J. Kansas Ent. Soc., 63 (1) : 92-100.

Byragi Reddy, T.B. and C.H. Aruna, (1990). Pollination ecology of Alangium lamarkii (Alangiaceae). Proc. Ind. Acad. Sci. (Plant Sci.), 100 (3) : 195-204.

Cameron, S. A., J. D. Lozier, J. P. Strange, J. B. Koch, N. Cordes, L. F. Solter, and T. L. Griswold, (2011). Patterns of widespread decline in North American bumble bees. Proc. Natl. Acad. Sci. USA. 108: 662-667.

Chand, H. and R. Singh, (1995). Effect of pollination by Apis cerana Fabr. on yield of mustard, Brassica juncea Linn. Indian Bee J., 57 (4) : 173174.

Cirudarescu, G., (1971). Pollinators of lucerne and factors influencing their activity in South Eastern part of Birsei Depression. Ann. Univ. Bucuresti. Biologie Animalia, 20 : 77-81.

Dashad, S. S., J.K. Sharma, and P. R. Yadav, (1994). Loose pollen grains carrying capacity of insect visitors apple bloom. Ann. Biol., 10(1):173-175.

Decourtye, A., E. Mader and N. Desneux, (2010). Landscape enhancement of floral resources for honey bees in agroecosystems. Apidologie 41:264277.

Elzinga, R.J., (1987). Fundamentals of Entomology. Prentice-Hall. University of Minnesota.

Free, J.B. and I.H. Williams, (1972). The transport of pollen on the body hairs of honeybees (Apis mellifera L.) and bumblebees (Bombus Spp. L.) J. App. Ecol., 9 (2) : 609-615.

Free, J.B., (1993). Insect pollination of crops. Academic Press; London, : 684 pp.

Freeman, C. E. and K.C. Head, (1990). Temperature and sucrose composition of floral nectars in Ipomopsis longiflora under field conditions. Southwestern Naturalist. 35: 423-426.

Galen, C. and M.L. Stanton, (1989). Bumblebee pollination and floral morphology: factors influencing pollen dispersal in the alpine sky pilot, Polemonium viscosum (Polemoniaceae). Amer. J. Bot., 76 : 419-426.

Gingrass, D., J. Gingrass and D. De Oliveira, (1999). Visits of honeybees (Hymenoptera : Apidae) and their effects on cucumber yields in the field. J. Econ. Entomol., 92 (3) : 435-438.

Grissell, E.E., (1999). Hymenopteran biodiversity: some alien notions. Amer. Ent., 45 (4) : 235244.

Hadimani, H.P., M. Farooq and C.R. Konda, (1998). Pollination in watermelon by honeybees. Kisan World, 25 (12) : 28.

Heard, T.A. and E.M. Exley, (1994). Diversity abundance and distribution of insect visitors to macadamia flowers. Environ. Entomol., 23 (1) : 91-100.

Heinrich, B. and P.H. Raven, (1972). Energetics and pollination ecology. Science, 176 : 597 - 600 .

Heinrich, B., (1975). Energetics of pollination. Ann. Rev. Ecol. \& Syst., 6 : 137-171.

Jitender Kumar. K.., V.K. Rao and J.K. Gupta, (1994). Pollination efficiency of bees visiting blossoms of Brassica campestris L. Var. toria in mid-hills of Himachal Pradesh, India, Indian Bee J., 56 (34) : 202-206

Jyothi, J.V.A., (1994). Visitation frequency and abundance of Apis cerana indica F. on mango (Mangifera indica L.) at Bangalore, India. Indian Bee J., 56 (1-2) : 35-36.

Jyothi, P.V., J.B. Atluri and C.S. Reddy, (1990). Pollination ecology of Moringa oleifera (Moringaceae). Proc. Ind. Acad. Sci. (Plant Sci.), 100 (1) : 33-42.

Kendall, D.A. and M.E. Solomon, (1973). The viability and compatibility of pollen on insects visiting apple blossom. J. Appl. Ecol., 10 : 847-853. 
Kevan, P.G. and H.G. Baker, (1983). Insects as flower visitors and pollinators. Ann. Rev. Entomol., 28 : $407-453$.

Koul, P., N. Sharma and A.K. Koul, (1993). Pollination biology of Apiaceae. Curr. Sci., 65 (3) : 219-221.

Mahanta, M. and A. Rahman, (1997). Studies on pollination of litchi (Litchi chinensis Sonn.) by honeybees (Apis cerana F.). Indian Bee J., 59 (2) : 74-75.

Mamood, A.N., G.D. Waller and J.R. Hagler, (1990). Dispersal of upland and pima cotton pollen by honeybees (Hymenoptera : Apidae) visiting upland male sterile flowers. Environ. Entomol., 19 (4) : 1034-1036.

Mc Call, C. and R.B. Primack, (1992). Influence of flower characteristics, weather, time of day and season on insect visitation rates in three plant communities. Amer. J. Bot., 79 (4) : 434-442.

Mohana Rao, G. and M.C. Suryanarayana, (1990). Studies on the foraging behaviour of honeybees and its effect on the seed yield in niger. Indian Bee J., 52 (1-4) : 31-33.

Mohana Rao, G., (1991). Studies on the floral biology and pollination requirement of scented methi (Trigonella corniculata Linn.). Indian Bee J., 53 $(1-4): 39-43$.

Mohana Rao, G., M. Lazar and M.C. Suryanarayana, (1984). Studies on floral biology and pollination of litchi, Litchi chinensis Sonn. Indian Bee. J., 16 : 7-11.

Ne Smith, D.S. and G. Krewer, (1999). Effect of bee pollination and $\mathrm{GA}_{3}$ on fruit size and maturity of three Rabbiteye blueberry cultivars with similar fruit densities. Hort. Sci., 34 (6) : 11061107.

Neeman, G., A. Dafri and S.G. Potts, (1999). A new pollination probability index (PP1) for pollen load analysis a measure for pollination effectiveness of bees. J. Apic. Res., 38 (1-2) : 1923.

Panda, P., B. Panda, and B.K. Sontakke, (1991). Foraging behaviour of honeybees on sunflower (Helianthus annuus L.) sown on different dates. Indian Bee J., 53 (1-4) : 44-49.

Pflumm, W., (1985). Influence of nectar supply rate on the number of flowers visited by a honeybee on each collecting flight. Oecologia, 66 : 207210.
Prakash, D.S., S. Baskaran and A. Mohandoss, (1993). Insect pollination of the guava, Psidium guajava Linn. Comp. Physiol. Ecol., 18 (2) : 60-64.

Price, P.W., (1984). Insect Ecology. Second Edition. John wiley \& Sons, New York: 162.

Priti, (1998). Abundance and pollination efficiency of insect visitors of onion bloom. Indian Bee J., 60 (2) : 75-78.

Rakesh Kumar, Lenin, J.K. and K. Chandran (1997). Studies on floral biology and foraging behaviour of honeybees on coconut palm Cocos nucifera L. Indian Bee J., 59 (4) : 238-239.

Rakesh Kumar, Lenin, J.K. and K. Chandran, (1996). Honeybee pollination of Psidium guajava L. Indian Bee J., 58 (4) : 206-207.

Ram, M.H.Y., (1980). The biology of flower : some aspects. Indian Sci. Congr. Assoc. Part II 67 th session, 1-6 Feb. 1980. Calcutta.

Ramadevi, K., J.B. Atluri and C. Subba Reddy, (1989). Pollination ecology of Zizyphus mauritiana (Rhamnacea). Proc. Ind. Acad. Sci. (Plant Sci.), 99 (3) : 223-229.

Reddi, E.V.B. and C.S. Reddi (1983). Pollination ecology of Jatropha gossypiifolia (Euphorbiaceae). Proc. Ind. Acad. Sci. (Plant Sci.), 92 (2) : 215-231.

Reddi, T.B. and C.H. Aruna, (1990). Pollination ecology of Alangium lamarkii (Alangiaceae). Proc. Ind. Acad. Sci. (Anim. Sci.), 93 (4) : 391396.

Richards, A.J., (1986). Plant Breeding System. George Allen \& Unwil, London. 529pp.

Rosa, J. F., M. Ramalho, D. Monteiro, and M. D. Silva. (2015). Permeability of matrices of agricultural crops to Euglossina bees (Hymenoptera, Apidae) in the Atlantic Rain Forest. Apidologie. 46(6) : 691-702.

Saraf, S.K.., (1987). Pollen gathering by honeybees in the Kashmir valley. Indian Bee J., 49 : 48-49.

Schmitt, J., (1980). Pollinator foraging behaviour and gene dispersal in Senecia (Compositae). Evolution, 34 : 934-942.

Shivanna, K.R. and B.M. Johri, (1985). The Angiosperm Pollen Structure and Function. Wiley Eastern Ltd., new Delhi : 171.

Shubharani R., V. Sivaram, and P. Roopa, ( 2012). Assessment of honey plant resources through 
pollen analysis in coorg honeys of Karnataka State. Int J Plant Reprod Biol. 4:31-39.

Sihag, R.C. and D.P. Abrol, (1986). Correlation and path coefficient analysis of environmental factors influencing flight activity of Apis florea F. J. Apic. Res., 25 (4) : 202-208.

Simpson, B.B. and J.L. Neff, (1983). Evolution and diversity of floral rewards. In : Hand book of Experimental Pollination Biology. (eds.) Jones, C.E. and Little, R.J. Van Nostrand Reinhold, New York.

Solomon Raju, A.J., P. Victor and C. Subba Reddy, (1999). Flowering phenology of some tropical plants of Kakinada. Visakha Sci. J., 3 (1) : 53 57.

Solomon, M.E., (1945). Tyroglyphid mites in stored products - methods for the study of population density. Ann. Appl. Biol., 32 : 71 - 75.

Spira, T.P., A.A. Snow, D.F. Whigham, and J. Leak, (1992). Flower visitation, pollen deposition and pollen tube competition in Hibiscus moscheutos (Malvaceae). Amer. J. Bot., 79 (4) : 428 - 433.

Subba Reddy, C., A.J.S. Raju and J.B. Atluri, (1997). Bee pollination in tamarind trees. Indian Bee J., 59 (3) : 178 - 179.

Thakur, D.K., O.P. Sharma, R. Garg. and G.S. Dogra, (1982). Comparative studies on foraging behaviour of Apis mellifera and Apis cerana indica on mustard. Indian Bee J., 44 (4) : 91 92.

Vithanage, V. and T.J. Douglas, (1987). Honeybee pollination of macadamia : Floral rewards and their effect on pollen flow. J. Apic. Res., 26 (4) : $261-269$.

Waddington, K.P., (1981). Factors influencing pollen flow in bumblebee pollinated Dalphinium viresences. Oikos, 67 : 153 - 159.

Wiklund, C., T. Eriksson, and H. Lundberg, (1979). The wood butterfly, Leptidea sinapsis and its nectar plants : a case of mutualism or parasitism?. Oikos, 33 (3) :358 - 362. 